\title{
図書館と地震被害
}

\author{
木原一雄 ${ }^{1}$ 加藤多恵子 ${ }^{2}$
}

著者抄録 : 日本をはじめ, 地形的に地震発生の可能性のある地域での図書館の地震対策は喫緊の課題 である。図書館での地震発生時での図書館, および図書館員の対応について述べる。図書館が地震 に遭遇した場合, まずは図書館利用者, 図書館スタッフの人命を守る, 次に図書館資料を守ること である。いずれにしても図書館の免震構造, および図書館内の設備の耐震の工夫は重要である。そ の中でも書架の構造, 固定などは地震発生被害を経験して, いくつかの教訓が得られている。日本 の阪神淡路大震災, カリフォルニア州で発生した2件の地震に関連して図書館が遭遇した被害につい て触れた。

キーワード : 図書館, 地震, 書架, 地震対策, 阪神淡路大震災, カリフォルニア州

\section{Damages by earthquake and libraries}

\section{KIHARA Kazuo ${ }^{1}$, KATO Taeko²}

\begin{abstract}
Author Abstract: In any region where earthquake occurs including Japan countermeasures against the damages by earthquake in libraries are urgent issues. This article describes how libraries and librarians solved and should solve the damages by earthquakes. When libraries encounter earthquake, at first not only libraries users but also library staff have to be saved or protected from such damages, and then needless to say libraries materials have to be protected too. Libraries needs be earthquake resistant not only in construction but also in libraries goods or facilities inside such as stacks or shelves. Looking at three cases, in Hanshin-Awaji Great Earthquake, in California State the article mentions how the libraries encountered the earthquakes, and the lessons from the earthquake damages.
\end{abstract}

Key words: library, earthquake, bookshelf, countermeasure against earthquake, Hanshin-Awaji Great Earthquake, California State

\section{1. はじめに}

1989年10月17日, 午後5時4分にマグニチュード 6.9の地震が米国サンフランシスコ湾エリアで発生 した（Loma Prieta地震と呼ばれる）。1994年1月17 日, 午前4時30分, ロスアンゼルスの北西20マイル のノースリッジでマグニチュード 6.7 の地震が発生 した。また，1995年1月17日午前5時46分にはいま だに記憶に新しい兵庫県南部地震（阪神淡路大震

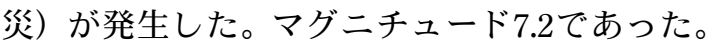

すでに図書館・文書館の防災対策として(参考文
献1)な゙)資料も作成されているので, 本記事では, 防災対策というより, 大震災の場合, 図書館でど ういう被害があり, どういう対応が必要であるか をまとめてみた。

地震と一口に言ってもその実態は種々である。 地震は他の災害と比べて瞬間的であり, 時間的余 裕が無いので, せいぜい5６分の間に地震発生か ら図書館が対応すべきことが決まってしまう。こ こに日ごろの防災対策と，防災訓練が必須である ことが明瞭である。図書館(図書館員)がすべきこと は, 図書館の建物が壊れない事が前提であるが,

\footnotetext{
1 キハラ株式会社（干101-0062＼cjkstart東京都千代田区神田駿河台3-5） Tel. 03-3292-3301 Fax. 03-3291-5198

2 独立行政法人科学技術振興機構 産学連携推進部（广102-8666 東京都千代田区四番町5-3） Tel. 03-5214-7993 Fax. 03-5214-8399 E-mail: tkato@jst.go.jp

1) Kihara Co. (3-5 Kanda Surugadai, Chiyoda-ku Tokyo, 101-0062)

2) Dept. of Technology Transfer Promotion, Japan Science and Technology Agency (5-3, Yonban-cho Chiyoda-ku, Tokyo, 102-8666)
} 
1）まずは人(図書館利用者と図書館のスタッフ)を 守ること，2）図書館資料を守ること，である。そ して, 地震から発生する火災, そして津波などに 代表される水の被害を抑えることである。

この場合, 図書館員はどういう図書館内の命令 系統で図書館利用者および自分たち図書館スタッ フを避難へとリードするかである。状況判断と非 難通路が重要となってこよう。こういった基本的 な原則を理解したうえで，地震対策をとることが 肝要である2)。

\section{2. 地震の大きさ}

通常, 地震は2つの方法でその大きさがわかる。 いわゆるマグニチュードと震度である。

表1 マグニチュード

\begin{tabular}{|l|l|}
\hline マグニチュード & 呼び名 \\
\hline $8 \sim$ & 巨大地震 \\
\hline $7 \sim$ & 大地震 \\
\hline $5 \sim 7$ & 中地震 \\
\hline $3 \sim 5$ & 小地震 \\
\hline $1 \sim 3$ & 微小地震 \\
\hline$\sim 1$ & 極微小地震 \\
\hline
\end{tabular}

上記では, マグニチュードで地震の規模が表さ れている。

マグニチュードは地震の規模を示す值で, 震源 で生じた自然現象の大きさを示す。マグニチュー ドが1増えると地震のエネルギーは約 32 倍になる。 2増えればエネルギーは32倍の32倍で, 約1,000倍に なる。したがって,マグニチュード8の巨大地震 (関 東大震災はマグニチュード7.9)のエネルギーはマグ ニチュード 6 の中規模地震の 1,000 回分に相当する ことになる3(4)。

震度はある地点での地震による摇れの度合いを 大きさで分類したものである。したがってマグニ チュードの尺度と違って, 人間的な尺度であると も言えよう。計測震度計で測定する。

以下表2を参考に示す。

困書館建築は他の建物と異なる空間構成である。 例えば可能なかぎり, 低層であること, 書架や閲 覧机の配置は十分配慮されている。地震の摇れに よって書架の倒壊があれば，当然書架に配架され ている図書などが落ちてくることもあり，閲覧机 の書架との距離によっては座って閲覧していた人 の逃げ場がなくなり, 図書の下敷き, 書架の下敷
表2 震度

\begin{tabular}{|l|l|}
\hline 震度 & 状況 \\
\hline 震度 0 & $\begin{array}{l}\text { 人には感じられないが地震計に記録さ } \\
\text { れる }\end{array}$ \\
\hline 震度 1 & 部屋の中でわずかな摇れを感じる \\
\hline 震度 2 & 電灯などの下げものがわずかに摇れる \\
\hline 震度 3 & $\begin{array}{l}\text { 家が摇れ, 戸がガタガタと音をたてる。 } \\
\text { 電灯が大きく摇れる }\end{array}$ \\
\hline 震度 4 & $\begin{array}{l}\text { 家が大きく摇れ, 置物が倒れたりする } \\
\text { ことがある }\end{array}$ \\
\hline 震度 5 弱 & 空ガラスが割れて落ちることがある \\
\hline 震度 5 強 & 棚から食器や本が落ちてくる \\
\hline 震度 6 弱 & 立っていることが難しい \\
\hline 震度 6 強 & 這わないと歩くことができない \\
\hline 震度 7 & $\begin{array}{l}\text { 建物が傾いたり, 壊れたりする。ひど } \\
\text { い地割れができる }\end{array}$ \\
\hline
\end{tabular}

(財) 大阪建築防災センター発行 『いえづくりと 家の防災』より

サンケイスポーツ 2004 年 9 月 29 日 記事から

きになる可能性もある。また, 書架がゆっくり倒 れてきた場合, 机に途中遮られて, その下に体を 位置した人は, 難を逃れられることもある。また 通常の家庭での震災同様, 足の踏み場もなく, 図 書が散乱している場合は逃げ道をふさがれてしま う。これらの災害を防ぐには, 当然, 書架が倒れ ないように, 資料が飛び出さないように, さらに 図書館建物自体を免震構造にするという方法があ る。ちなみに, 建築法規では平成7年法律第123号 で,「特定建築物を耐震診断し, 耐震改修し, 地震 による建築物の倒壊の被害から国民の生命, 身体 および財産を保護する」となっている。特定建築 物は法第 2 条令 1 条に定められている。この特定建 築物は(1)耐震診断, と, (2)耐震改修を行うこと, が 義務付けられている。(1)と(2)の指針は国土交通大 臣が行う。所管行政府として都道府県知事（建築 主事を置かない市町村）か, 市町村長, 特別区長 らが診断, 改修に関して(1)指導, (2)助言, (3)指示 など行う。もちろん図書館はこの特定建築物に該 当する5)。

\section{3. 図書館が遭遇した地震と地震後の 対応}

\subsection{9年10月17日午後5時4分に発生： Loma Prieta地震}

カリフォルニア北部で死者 63 人を出したマグニ チュード6.9の地震で, 60 億ドルもの被害が出た。 
地震はSanta Cruz 郡が震源地であったが, スタン フォードの南方約40マイルであった。それでもス タンフォード大学では, 数十のキャンパス内の構 造物に被害があり, 1999年までに同大学は 2 億 5,000 万ドルもの費用を使ってキャンパス内の修復を行っ た。図書館内の書架は転倒し, 地震後数日は図書 館スタッフおよびボランティアが75万冊の図書を 再配架した4)。また震源地Santa Cruzの公共図書館 は10ある分館のうち9館の図書が床に落ち, 足の踏 み場もなかったが, 多大の時間をかけて図書の再 配架と掃除を行った。それでも図書館スタッフと ボランティアの大いなる尽力で地震後の翌週の月 曜日（10月23日）にはほとんどの分館で開館でき た。ボランティアは,カリフォルニア大学 Santa Cruz 校の学生, 通りがかりの人々などであった。地震 で, 停電にはなっていたものの, フラッシュライ 卜を使い復旧にあたった。その結果，あまりの迅 速な開館に地震の被害を思い起こせないほどであっ たという ${ }^{677 。}$

ただし，24日の火曜日にCentral Branchの図書館 利用者, スタッフは避難せざるを得なくなった。 理由は同図書館の2階部分のほこりの中のアスベス 卜量が安全である許容量を超えたためであった。

\subsection{4年1月17日午前4時30分に発生： Northridge 地震}

ロスアンゼルスの北西20マイルで死者51名を出 したマグニチュード 6.7 の地震で, 震源地から 1 マ イル離れたカリフォルニア州立大学ノースリッジ 校 (California State University, Northrigde CSUN) の キャンパス全体の被害は4億ドルにも上った。30秒 以内で, 大学の建物, 電気, 水, 電話が使用不可 となった。この地震は学期の休み中で, しかも早 朝に起きたので, 人的な被害は非常に少なかった。 建物被害は甚大で，修復不可の建物もあった。し たがって直ちに, 芝生や運動場, 駐車場を利用し て仮校舎が建てられた。その結果，授業は地震発 生から4週間後に開始できた。これは当初計画した より 2 週間も期間を早めることができた。図書館本 館も使用不可になったため, 1994年の春学期は学 生達に別の図書館を利用するよう案内した。シャ トルバスを出して学生達を協力図書館であるカリ フォルニア大学ロスアンゼルス校に運んだ。また CSUNのレファレンスライブラリアンは, 同大学の 学生の利用で多忙となった協力図書館の労働負担 を軽減するためにそれらの図書館に派遣された。 またLexis-Nexis, CARL Uncover, First Search といっ
たデータベースのアクセスには料金無料の電話番 号を設定した。図書館建物被害で言うなら，コン クリートの構造的損害, アスベスト污染があり, また書架から図書はほとんどすべて落下し，床の 図書が散乱し, 足の踏み場もなかった。耐震構造 の図書館建築の必要は言うまでもないが, 最新の 書架基準を満たす図書館書架の補強と支え留めが 必要であることが確認された。確かに1971年に起 きたサンフェルナンド地震では, 同大学は震源地 から25マイル離れていたにもかかわらず, 書架が 倒壊したが, 今回の地震では図書60万冊が床に落 下したにもかかわらず，書架は無傷であった。資 料は資料で貴重ではあるが，まず人々の安全確保 が第一である。日頃からの避難訓練，避難具の準 備など, 多くの地震防災の教訓が得られた ${ }^{8)}$ 。

\subsection{5年1月17日午前5時46分にマグニチュー \\ ド7.2の地震が発生した : \\ 兵庫県南部地震（阪神淡路大震災）}

この地震によって図書館や公文書館は建造物や その内部備品, 資料や書籍類が多大の被害を被つ た。早朝であったため, 図書館利用者, 図書館ス タッフへの被害が無かったことは不幸中の幸いで あったと言えよう。一般に知られているのは，次 のようなことであった。

(1)摇れの方向によって書架の転倒や図書の落下 が大きく異なった。

(2)スチール製に比べて木製書架のほうが倒壊し にくかった。特に木製の複式傾斜書架は, 倒壊が 少なかった。

(3)書架の床（補強されている床が前提）止めは 効果があったと言える，したがって止める場所の 強度の確認が必要である, つまり, 芯のない床に 床止めしても無用である。壁止めする場合も壁の 中が空洞であればこれも役に立たない。

(4)書架を床止めできなくても，4～5メートルく らいの単位で，書架を連結すると効果がある。

(5)棚から本が落ちるエネルギーは，石のブロッ クが落下するそれと同じと考えると良い。書架の 棚板をほんのわずかでも後方に傾斜させると落下 しにくくなる。

(6)図書を暫定的に置いておくブックトラックの 場合, ブックトラックのキャスターは固定しない ほうが良さそうである。実験では，ブックトラッ クはぐるぐる回ることはあっても摇れによって遠 くまで飛んでいくことはなかった。

(7)書架が転倒した際，隣の閲覧机がストッパー 
になり，その机の下に避難空間ができていた。閲 覧テーブルは, その下が避難スペースとなり得る。

いずれにしても耐震構造を満たすこと, 四書館 の書架, 備品に配慮する, 日ごろからの避難訓練, 避難具の装備が重要である, またものである資料 を大切にする, つまり貴重書は日ごろからしっか りと保管しておく, 一般図書·資料と人命の場合, 人命に重点を置く, ことが肝要である。今回の地 震被害を教訓に「地震と図書館 : 図書館家具 耐 震試験リポート」が出されているので, それを参 照されたい9)。

\section{4. 図書館の地震対策について}

これまで簡単に図書館と地震の被害について述 べてきたが, 図書館の地震対策で大きなことは書 架の扱いである。図書館の命である資料を配架し てある書架の被害が大きな災害を引き起こす。開 館時間での地震であれば, 当然人の命がかかわつ てくる。いずれにしても地震の横摇れ, 縦摇れに 耐性のある構造的に補強された書架, そして床に 特別な固定装置を付けねばならない。米国の場合, 中西部とカリフォルニアでは, 地震の状況が大き く異なり, したがって地震の多いカリフォルニア では耐震書架設定の要求レベルが高いのは当然で ある。1995 Uniform Building Codeにはこの必要条件 が規定してある。また, 壁に立てかけた書架はあ る意味で安全であり,これに縦摇れに耐性を持た

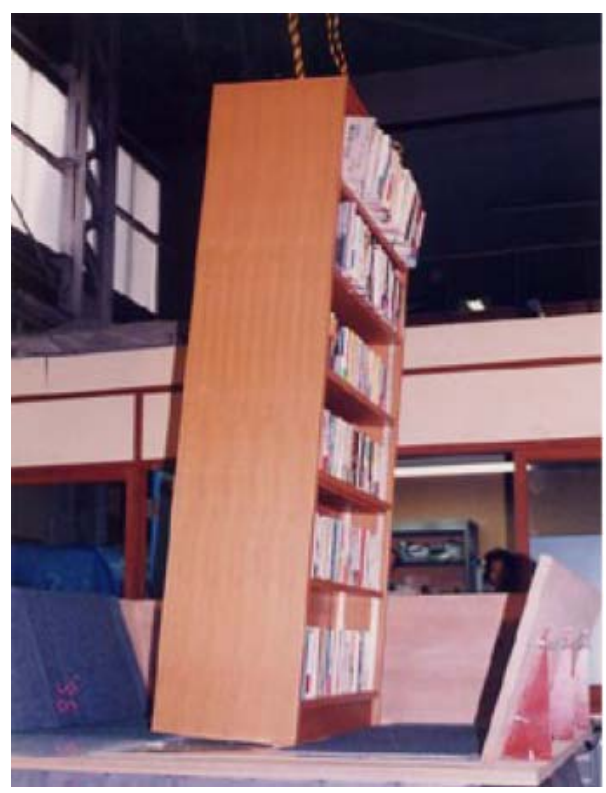

写真1 木製書架の耐震実験9)
せるために床または壁の固定が必要であるといっ たことは周知の事実である10)。

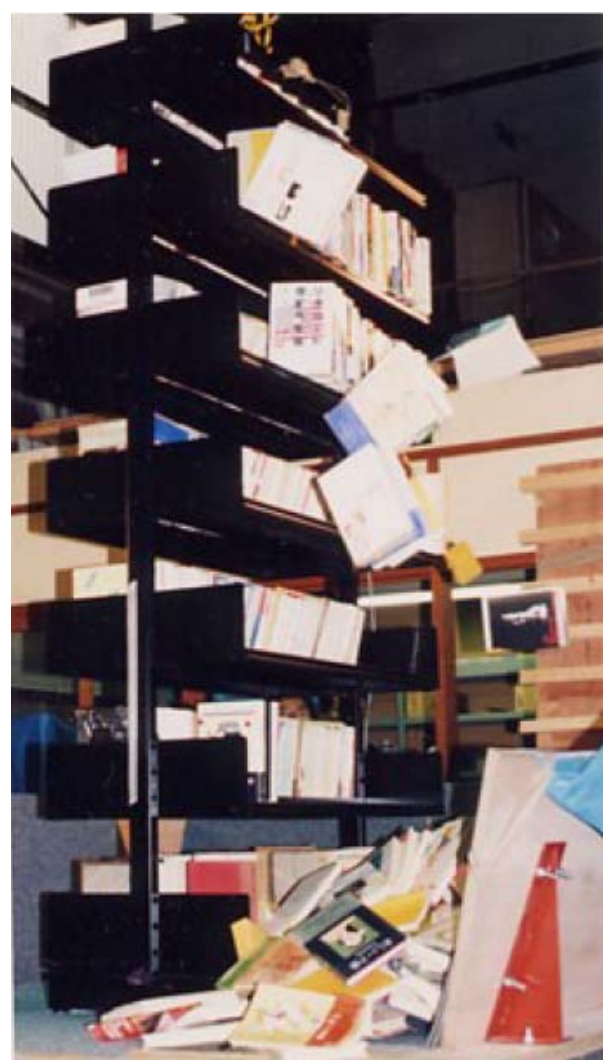

写真2 スチール書架の耐震実験9)

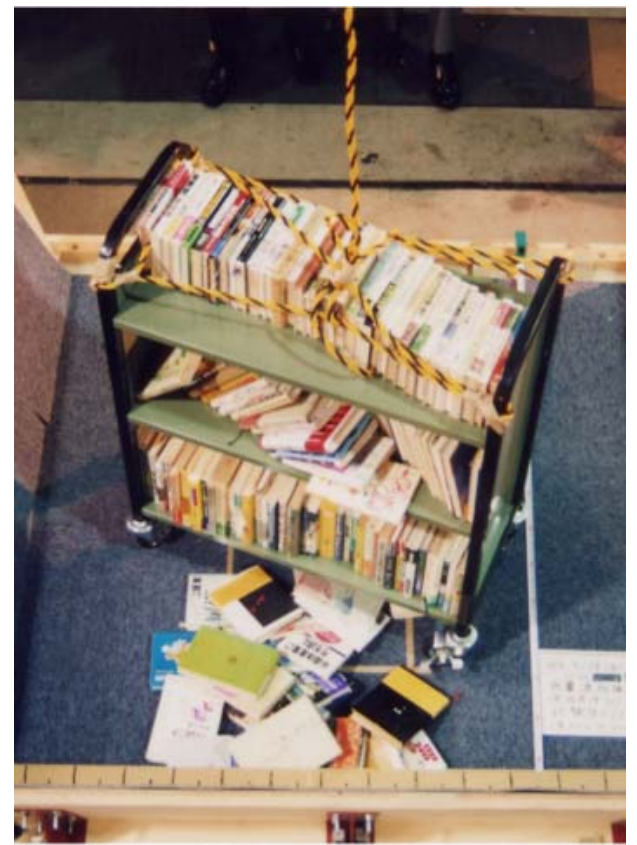

写真3 ブックトラックの耐震実験9) 


\section{5. 最後に}

図書館の地震対策は，地震国である日本の場合 日ごろから対策と避難訓練をする必要があるのと 同様, 特に地震国である日本やカリフォルニアで は絶対的にしなければならない。阪神淡路大震災 を教訓に書架の被害と対策, 書架・備品の耐震対 策，図書館防災の基本が「図書館・文書館の防災 対策」で記載されている11)。

また, 米国では災害計画その予防, 準備, 対応,
復興という資料も出ている ${ }^{12)}$ 。

またそれらに関する資料の文献リストも出てい る13)。

いずれも備えあれば憂いなしであるが，地震は 予告なしに訪れる, そして, その直後の対応には 冷静な判断が求められる。それゆえに, 地震経験 者の体験をもっと公開してほしいと願う。特に図 書館は人が館内で動いている。人命をいかに守る か図書館員の対応は重要である。

\section{参考文献}

1）小川雄二郎監修. 図書館·文書館の防災対策. 東 京, 雄松堂, 1996 . Viii, $260 \mathrm{p}$.

2) "Library Earthquake Preparedness Planning: How to make sure that your library is ready for the "Big One". (online), available from <https:// www.haworthpress. com/Store/Article Abstract.asp?sid=0PW6PFLM1 ATX9PMNH30 CEKGEK7G6EUH5\&ID=11571>, (accessed 2005-06-21).

3) “マグニチュードと地震”。(オンライン), 入手先, $<$ http://contest.thinkquest.gr.jp/tgj2000/30295/ glossary/magni.html>, (参照2005-07-04).

4）“地震・マグニチュード”。(オンライン), 入手先 $<$ http://www.advnet.comjp/s-index/index/no6/ sf061000/s061004.html>, (参照2005-07-04).

5）中村忠實．絵ときでわかる建築法規．東京，オー 么社出版局, 2002.p.158-159.

6) "15 years after Loma Prieta earthquake, tardy temblor yields trove of data". (online), available from <http:// news-service.stanford.edu/news/2004/october 13/ Quakes-1013.html>, (accessed 2005-06-20).

7) "Loma Prieta Earthquake and the Saint Cruz Public Libraries". (online), available from $<$ http:// www.santacruzpl.org/history/disaster/89 quake/ clean.shtml>,(accessed 2005-06-20).

8) "Disaster Planning for Libraries: Lesson from California State University Northridge". (online), available from <http://www.access.gpo.gov/su_docs/ fdlp/pubs/proceedings/99pro29.html $>$, (accessed 2005-06-21).

9) 地震と図書館：図書館家具 耐震試験リポート. 東京, キハラ, 1998. 15p.

10) "Libris DESIGN Website-Library Stacks are Shelving. 5. Seismic issues". (online), available from $<$ http://www.librisdesign.org/docs/stack_shelving. $\mathrm{html}>$, (accessed 2005-06-21).

11）1)に同じ. 第5章. p.215-257.

12) "Disaster Planning: prevention, preparedness, response, recovery". (online), available from <http:// webworld.unesco.org/safeguarding/en/pdf/text_sini/ pdf $>$, (accessed 2005-07-14).

13) "Disaster Manual CH.6. Reference Section. 6. Bibliography". (online), available from $<\mathrm{http}: / /$ www.wnylre.org/pub/disan6.htm>, (accessed 200506-20).

\section{その他の参考文献}

"Planning for the Big One; On Shaky Ground 2. Scenario". (online), available from <http:// sorrel.humboldt.edu/ geodept/earthquakes/ shaky2_scenario.html>, (accessed 2005-06-20).
"Library Worthy Introduction. David C. Weber". (online), available from <http://www.redgravehstein. com/people/gs/mlis/200/weber.htm $>$, (accessed 2005-06-20). 